\title{
New Trends in Higher Education in the Globalizing World: STEM in Teacher Education
}

\author{
Nilay Türk ${ }^{*}$, Nurdan Kalaycı, Havva Yamak \\ Faculty of Education, Gazi University, Ankara, Turkey
}

Copyright $\bigcirc 2018$ by authors, all rights reserved. Authors agree that this article remains permanently open access under the terms of the Creative Commons Attribution License 4.0 International License

\begin{abstract}
One of the main objectives of education, which raises individuals that the society needs, is to resource labor force that will provide the development of the society by maintaining the economic, social, scientific

curriculum for pre-service teachers to gain these competencies. Training teachers during pre-service period rather than in-service training will play a crucial role to gain the expected results from the approach.
\end{abstract} and technological advances. Many countries that aspire to have an advanced economy and technology aim to build a society that is advanced at Science, Technology, Engineering and Mathematics (STEM) and have sustainable development in these fields, and this has been one of the main educational strategies of those countries. STEM education has a strategic importance for our country to maintain the competitive power on international scale. This research aims to conduct a needs analysis towards the curricular design of STEM education to be proposed for the undergraduate programs of science education at education faculties. The study holds a descriptive model and qualitative methods were used. The study group consists of 12 faculty from Science, Mathematics, Computer and Instructional Technologies at Faculty of Education, and from the Department of Mechanical Engineering, Faculty of Engineering at Gazi University; 15 science teachers who work at the schools which have different socio-economic levels in Ankara, and 42 sophomore students who study at the Department of Science Education at Gazi University Faculty of Education. Content analysis was used as the data analysis method. Findings of the study reveal that there are no studies conducted to integrate different fields into teacher education programs, there are no courses related to STEM education integrated into the curriculum, and the knowledge and skills pre-service teachers should gain to implement this approach in their professional teaching career do not exist in the curriculum. In addition, it was found that most of the teachers believe teacher collaboration; they associate their courses mostly with mathematics and information technologies. Likewise, it was identified that the main reason behind why the teachers cannot teach through interdisciplinary approach is due to teacher related reasons. Concerning the pre-service education, The Ministry of National Education and education faculties should work collaboratively, determine the teacher competencies and try to develop undergraduate

Keywords STEM Education, Integrated STEM Education, Integrated Teaching Knowledge

\section{Introduction}

With the latest industrial revolution 4.0, societies have been in a new quest to be able to cope with the global developments, to compete within the economic and technological arena, and as a consequence of these quests, it has been realized that education is of great importance in the success of the societies' sustainable development. The society's need for labor force, which produces knowledge and makes innovations, has resulted in a similar transformation in education as well: Education 4.0. As a topic of conversation like Industry 4.0, Education 4.0 is an educational system that supports students to make innovations resulting from knowledge production [40]. One of the main objectives of education, which raises individuals that the society needs, is to resource the qualified labor force that will provide the development of the society by maintaining the economic, social, scientific and technological advances. Therefore, in order for a country to be able to reach this goal, it should design the curricula by which the individuals and society's social, economic, cultural and global requirements can be met and in such a manner that the individuals can cope with the local and global changes and advances [78, 34]. In this regard, many countries which would like to develop technologically and have an advanced economy has adopted the educational strategy that paves the way to build a society which have the ability in Science, Technology, Engineering and Maths (STEM) [89].

STEM education has been one of the key matters discussed in the education world. The United States of 
America is the leading country which introduced STEM approach. In the 1970s, the USA started curriculum development studies to raise individuals who can meet the needs of the country and published National Science Education Standards (NSES) in 1966. In addition, the USA implemented an engineering curriculum in schools at primary and secondary education since 1990 [72]. This approach which used to be called SMET has then referred to STEM education [80]. Some projects such as No Children Left Behind didn't reach a success and couldn't meet the requirements of labor market, which has resulted in the adoption of STEM education again. Eventually, STEM has been viewed as an approach that prevents the country from losing the leadership in science, technology, economy and defense globally, and has been one of the important policies of the government. In 2010, a report was published related to this subject [43].

In the later years, many other countries (England, Singapore, Korea, Australia etc.) started to include STEM into their education systems and tried to extend this approach $[31,45,54,87]$. This approach has been largely accepted as it allows students to collaborate, communicate, think critically and creatively (4Cs) [59-60]; gives the opportunity to the students to gain the skills in four fields at the same time; creates an environment to teach engineering, science, technology and mathematics.

It is a quite recent debate that STEM education has been discussed in Turkey. The Ministry of National Education made the first base on this subject in 2014 with Scientix project as a national support point [66]. Furthermore, it published a report related to STEM education in 2016 and laid emphasis on the importance of STEM education. In the report, to integrate this approach into our education system, it was stated that the Ministry of National Education should prepare a strategic plan, revise the curricula, and provide the technological infrastructure and required materials. The STEM approach, which used to correspond mostly to private institutions, has gradually gained importance by the state.

The studies in higher education on this subject began in 2009. Hacettepe University is the first to found STEM center (laboratory), and İstanbul Aydın University, METU, Bahçeşehir University, Rize University and Muş Arparslan University was to follow. These institutions still conduct projects in collaboration with various institutions. In 2014, hosted by İstanbul Aydın University, many lecturers collaborated and prepared the STEM Education Turkey Report [3]. Furthermore, in the same year TUSİAD published the research called "Demand and Expectations to The Labor Force Trained in STEM [89]. Thus, Turkey's situation related to STEM education has been introduced, the need for this education approach has been identified and some suggestions have been made about how to implement this approach.

STEM education has a key role for our country to maintain its global competitiveness [23]. The research that has been conducted with regard to STEM will contribute to the economy of the country and to the science, technology, mathematics and engineering education [64]. While education reforms related to STEM education around the world are still on the run for the last 20 years $[46,47,48,49$, $71,73,74,75]$, only few universities in Turkey have been conducting STEM projects individually or in collaboration with industrial organizations [3, 4, 44, 89, 90]. In 2017 global innovation index ranking, Turkey is the $43^{\text {rd }}$ out of 127 countries [29] and the $25^{\text {th }}$ out of 180 countries according to WIPO Economics and Statistics Series report for patent application ranking [91]. These results indicate that the projects and research conducted by Turkey have played a prominent role in raising the individuals who can design and manage smart production systems by keeping up the digital transformation dynamics in industry 4.0.

\section{STEM Education}

There is not a standard definition of STEM created by using the initials of Science, Technology, Engineering and Mathematics [62]. While William [92] defines STEM education as an approach that supports student participation by using engineering and technology, and that improves students' learning in science and mathematics, Israel, Maynard and Williamson [51] defines it as an approach that emphasizes student centered and collaborative learning beyond the context of four STEM fields. STEM education basically removes the borders between the disciplines by making the students to comprehend the world as a whole rather than parts [63].

However, since there are different opinions about how to integrate the STEM fields such as interdisciplinary, multidisciplinary and transdisciplinary, there is still need for the research trying to assert which approach is more effective [25]. Bybee [20] states there are nine ways of STEM integration whereas Drugger [28] addresses four. Common characteristic of these opinions is that STEM terms and skills should be integrated to the real world problems or incidents so as to make student learning more meaningful [25]. Recently, integrated STEM education approach, which four disciplines are evenly effective, has been accepted worldwide. In Turkey, integrated curriculum approach first existed in the primary school curricula of 1924, 1926, 1936, 1948 and 1968, and then of the curricula of life sciences, social sciences, science courses $[27,82]$. When the latest curricula developed by The Ministry of National Education are analyzed, it may be easily recognized that the curricula are to be integrated using the interdisciplinary approach [67-70].

The research indicates that the integrated approach in education has a positive effect on students' academic achievement and their attitudes towards the lesson $[8,11$, $12,14,15,55]$. Hartzler [41], within the meta-analysis study carried out using thirty studies, states that integrated instruction increases students' academic achievement, interest and self-confidence. Elliot, Oty, McArthur and 
Clark [30] states that the math education integrated with science affects the students' attitude towards the course, their critical thinking and problem solving skills positively. The STEM organizations around the world have accepted the integrated STEM education for more than twenty years [81]. Accordingly, in order for integrated STEM education to be implemented by the schools, projects and academic studies have been conducted.

Starting from preschool to secondary education, one of the most important factors in education is the teacher. Teachers play a critical role in preparing and encouraging the students for education [17, 33, 43, 79]. Recently, in order for the students to have the expected success, teachers play a prominent role. It is really important that the teachers, who have the responsibility to design the entire learning process, should have a pedagogical content knowledge of STEM and professional teaching knowledge. This knowledge can contribute to the teachers in teaching STEM disciplines to students for the students' daily lives and choices of profession $[43,76]$. In this way, students can learn the terms in science, technology, engineering and mathematics, and they will try to find solutions to the real world problems. STEM education is focused on the problems which focus on interdisciplinary, authentic and given within a context [61]. Discovery, problem solving and research based methods play a key role in the integration of STEM fields [65].

Along with the changing conditions of the 21 st century, there is still a need to educate teachers who can teach the youth in the way that they can work on STEM research, and who can design and use the learning environments effectively. Therefore, teacher education programs are really important. The interaction between science and maths shows that it is not enough for a teacher to have a teaching knowledge only in their major field in order to raise labor force that our country needs [23]. The studies that analyses teachers' use of similar fields to their major field reveal that there is still a problem with that. For example, pre-service teachers who studied physics are not satisfactory at maths, and maths teachers cannot use math knowledge while implementing science experiments [10, 26]. The teachers who will implement STEM education need many courses and workshops which show how to integrate STEM fields while trying to solve real world problems in collaboration [83]. In this context, Çorlu [22] proposed a model to the researchers who study on teacher education. The model, which is conceptualized as Integrated Teaching Knowledge, is based on Shulman [84], Hill, Schilling \& Ball [42] and his doctoral dissertation [21].

According to this model, STEM teacher:

- Has a professional level content knowledge.

- Has a professional level pedagogical content knowledge.

- Has the knowledge another STEM field apart from field of specialization. This knowledge brings competency as a STEM practitioner for field education.

- Develops the knowledge related to field by collaborating with the colleagues. As a result of this collaboration, professional learning communities are formed and collaboration between group teachers is improved.

There are few studies conducted to raise the pre-service teachers' in integrated teaching knowledge in Turkey [66]. Therefore, major field teacher education programs such as science, technology, engineering (design) and mathematics teaching should include courses that support integrated teaching knowledge, and there should be professional communication and collaboration opportunities for the pre-service teachers from similar fields [22]. However, considering the undergraduate programs of education faculties, there is only one private university that has STEM integrated courses.

Within the scope of the projects run by STEM units at some universities in Turkey, there are seminar and workshop opportunities for the teachers. However, because these opportunities are teacher dominated, it is still criticized that pre-service teachers are not educated through the needs for the twenty first century. In Turkey, after STEM has started to be implemented in private and state schools, the idea that pre-service teachers should be educated with the necessary professional knowledge, skills and experience to apply in the institutions they will work has become popular. In addition, in the Science Curriculum that MONE published in 2017, by integrating some engineering implementations, the transition to STEM education started. In this context, it has come into prominence to identify if the undergraduate programs have weaknesses in educating pre-service teachers.

Taking the above mentioned reasons into consideration, this study aims to conduct a needs analysis towards the curricular design of STEM education to be proposed for the undergraduate programs of science education at education faculties.

The research questions are as follows:

1. What are lecturers, teachers and pre-service teachers' opinions on;

1.1. STEM education?

1.2. Integrating teaching knowledge into teaching profession?

1.3. The Teacher Education Programs in Acquiring Integrated Teaching Knowledge?

2. What are the proposals of lecturers' and teachers' for teacher education programs?

3. What are the opinions of lecturers' on their situation of having the integrated teaching knowledge?

4. What are the science teachers' opinions on the collaboration with the teachers that teach other courses?

5. Which other courses do the science teachers 
associate their courses with?

6. What are the factors that cause problems for science teachers in associating their courses with other courses?

\section{Method}

\subsection{Model}

As this study focuses on the lecturers, teachers and pre-service teachers' opinions on STEM education and teacher education programs, the descriptive model was used. Descriptive studies try to define and identify a situation as exactly, carefully and in their own terms as they are $[19,58]$.

\subsection{Population and Sample}

This study includes the needs analysis done for STEM education curriculum design to be proposed for science teacher education undergraduate programs at education faculties. In the needs analysis democratic approach was preferred. According to this approach, study group was determined through maximum variation sampling principles and method. The aim of ensuring the variation does not mean generalization. The aim of the variation is to identify if there is any difference or similarities between the lecturers, teachers and pre-service teachers' opinions on STEM education and integrated teaching knowledge.

As STEM education involves the fields of Science, Technology, Engineering and Mathematics, the population of the lecturers were chosen from Science Education, Mathematics Education, Computer and Instructional Technology Education departments, which are all from Gazi University Faculty of Education, and from Mechanical Engineering department from Faculty of Engineering at Gazi University. All the 12 lecturers were the ones who carry out and follow studies in the field of STEM education. Three lecturers from each department were interviewed.

Table 1. Information of Lecturers

\begin{tabular}{|c|c|c|c|c|}
\hline Lecturer & Gender & Academic Title & Faculty & Department \\
\hline L1 & Female & Professor & Faculty of Education & Science Education \\
\hline L2 & Male & Associate professor & Faculty of Education & Science Education \\
\hline L3 & Male & Professor & Faculty of Education & Science Education \\
\hline L4 & Female & Assistant professor & Faculty of Education & Mathematics Education \\
\hline L6 & Male & Associate professor & Faculty of Education & Mathematics Education \\
\hline L7 & Male & Associate professor & Faculty of Education & Mathematics Education \\
\hline L8 & Male & Associate professor & Faculty of Education & Computer and Instructional Technology Education \\
\hline L9 & Female & Associate professor & Faculty of Education & Computer and Instructional Technology Education \\
\hline L10 & Male & Research Assistant & $\begin{array}{c}\text { Faculty of } \\
\text { Engineering }\end{array}$ & $\begin{array}{c}\text { Faculty of } \\
\text { Engineering }\end{array}$ \\
\hline L11 & Female & Research Assistant & Mechanical Engineering \\
\hline L12 & Male & Research Assistant & Faculty of Education & Computer and Instructional Technology Education \\
\hline
\end{tabular}

While the population of teachers in the study comprised of science teachers who work at schools from different socio-economic levels in Yenimahalle, Mamak, Çankaya during 2015-2016 academic year, and the sample of the study were 15 science teachers who volunteered to participate in the study. The schools, which are all in Ankara, were chosen through random sampling method. 
Table 2. Information of Teachers

\begin{tabular}{|c|c|c|c|c|c|c|}
\hline Teacher & Gender & District & Faculty & Department & $\begin{array}{c}\text { Duration of } \\
\text { Service }\end{array}$ & $\begin{array}{c}\text { Degree of } \\
\text { Education }\end{array}$ \\
\hline TE1 & Female & Yenimahalle & Faculty of Sciences & Biology & 19 & Bachelor \\
\hline TE2 & Male & Yenimahalle & Faculty of Sciences and Literature & Biology & 16 & Master \\
\hline TE3 & Female & Yenimahalle & Faculty of Sciences & Biology & 22 & Bachelor \\
\hline TE4 & Female & Yenimahalle & Faculty of Sciences and Literature & Chemistry & 22 & Bachelor \\
\hline TE5 & Female & Yenimahalle & Faculty of Sciences & Biology & 14 & Bachelor \\
\hline TE6 & Female & Çankaya & Faculty of Education & Science Education & 9 & Bachelor \\
\hline TE7 & Male & Çankaya & Faculty of Education & $\begin{array}{c}\text { Chemical Science } \\
\text { Education }\end{array}$ & 21 & Bachelor \\
\hline TE8 & Female & Çankaya & Faculty of Education & $\begin{array}{c}\text { Chemical Science } \\
\text { Education }\end{array}$ & 23 & Bachelor \\
\hline TE9 & Male & Çankaya & Faculty of Education & Chemical Engineering & 20 & Bachelor \\
\hline TE10 & Female & Çankaya & Faculty of Education & Science Education & 2 & Bachelor \\
\hline TE11 & Female & Mamak & Faculty of Education & Science Education & 14 & Bachelor \\
\hline TE12 & Female & Mamak & Faculty of Education & Chemical Science & 20 & Bducation \\
\hline TE13 & Male & Mamak & Faculty of Sciences & Chemistry & 24 & Bachelor \\
\hline TE14 & Male & Mamak & Faculty of Sciences & Biology & 26 & Bachelor \\
\hline TE15 & Male & Mamak & Faculty of Sciences & Chemistry & 18 & Bachelor \\
\hline
\end{tabular}

Table 3. Information of Pre-Service Teachers

\begin{tabular}{|c|c|c|c|c|c|}
\hline Pre-Service Teacher & Gender & $\begin{array}{c}\text { Pre-Service } \\
\text { Teacher }\end{array}$ & Gender & $\begin{array}{c}\text { Pre-Service } \\
\text { Teacher }\end{array}$ & Gender \\
\hline PST1 & Female & PST15 & Female & PST29 & Female \\
\hline PST2 & Female & PST16 & Female & PST30 & Female \\
\hline PST3 & Male & PST17 & Female & PST31 & Female \\
\hline PST4 & Female & PST18 & Female & PST32 & Female \\
\hline PST5 & Female & PST19 & Female & PST33 & Female \\
\hline PST6 & Female & PST20 & Female & PST34 & Female \\
\hline PST7 & Female & PST21 & Female & PST35 & Female \\
\hline PST8 & Female & PST22 & Male & PST36 & Female \\
\hline PST9 & Female & PST23 & Female & PST37 & Female \\
\hline PST10 & Male & PST24 & Female & PST38 & Female \\
\hline PST11 & Female & PST25 & Female & PST39 & Female \\
\hline PST12 & Female & PST26 & Female & PST40 & Female \\
\hline PST13 & Female & PST27 & Female & PST41 & Female \\
\hline PST14 & Female & PST28 & Female & PST42 & Female \\
\hline
\end{tabular}

The population of pre-service teachers in the study comprised of sophomore level students who study Science Teacher Education at Gazi University, Faculty of Education in 2015-2016 academic year. In this part of the study, it is aimed to reach the whole population. Although 57 students participated in the research, only 42 students' answers were included for research data, and the rest of the students' answers (15) were excluded as the answers went beyond the scope of the results. There were 39 female and 3 male students who participated in the research.

\subsection{Data Collection Tools and Data Collection}

A semi-structured interview form was used in the study. In the forms used for the lecturers, there are five questions while there are seven questions in the forms used for teachers. The questions are all open ended. For the pre-service teachers, a questionnaire was used which included three questions.

In the preparation of the interview forms and the questionnaire, the researcher consulted two curriculum 
development experts so that the questions should firmly be related to the goal and sub-goals of the study. To test the validity of the form and questionnaire, a pilot implementation was conducted on three teachers, five pre-service teachers and two lecturers. After this implementation, the forms were put into the final form. The interview was implemented as a face to face interview and the questionnaires were filled out in an environment accompanied by the researchers.

To ensure the external validity of the study, raw data were stored so that others could analyze when needed, and they were described in detail. This detailed description reduces the possibility of research results that may be affected by subjective assumptions and preconceptions, and it serves as a guide for the future researchers that may work on similar types of research.

\subsection{Data Analysis}

Content analysis method was used to analyze the research data. The main purpose of the content analysis is to reach the terms and relations that can describe the data [94]. Content analysis is a form of comment that is usually used to discover the common senses in a variety of document contents aimed at structuring and classifying these senses, which makes it easier to generalize the from qualitative to quantitative [32]. The research data were analyzed in four steps: 1 . Code the data, 2 . Identify the themes, 3. Organize the codes and themes, 4. Describe the findings.

The steps in data analysis are as follows;

- Some abbreviations were identified for each study group. Then the lecturers, teachers and pre-service teachers' answers for the interview and questionnaires were recorded and computerized considering these abbreviations.

- The answers given for each research question were put together considering these abbreviations.

- The answers were grouped according to their similarities,

- Codes were set with regard to original opinions and put into tables.

- Themes were identified based on the codes,

- Codes were ordered within a descending sort according to themes that they belong to. As a matter of qualitative method principles, the interviews conducted were recorded without making any change in the participants' answers, and the content analysis was implemented to the collected data recorded. To ensure the internal validity, researchers coded the data and identified the theme that could describe the coded data. Then the researchers gathered and discussed about the codes and themes they prepared on computer. The codes and themes were put together related to their similarities or differences, and the necessary corrections were made.

To ensure the internal validity, the relevance of the tables according to the research questions was analyzed by two experts specialized in the fields of assessment and evaluation, curriculum and instruction. The experts also expressed their opinions on the internal consistency of the data, and some parts were reexamined and the tables were revised. The tables that include the codes and themes identified through the opinions and answers from the lecturers, two teachers and five pre-service teachers were discussed, and they were put into the final form.

To ensure the external validity in the study, all the steps related to the sampling strategy, preparation of data collection tools, data collection and analysis in detail.

\section{Findings}

In this section, the research findings were given within the subtitles referring to the questions that were answered by the participants. The following abbreviations were used for the frequencies that were put into the table. The descriptions related to the abbreviations are shown in the table.

Table 4. Meaning of frequency

\begin{tabular}{|c|c|}
\hline $\mathrm{f}_{\mathrm{l}}$ & Frequency of lecturers \\
\hline $\mathrm{f}_{\mathrm{te}}$ & Frequency of teachers \\
\hline $\mathrm{f}_{\mathrm{pst}}$ & Frequency of pre-service teachers \\
\hline $\mathrm{f}_{\mathrm{t}}$ & Frequency of theme \\
\hline $\mathrm{f}_{\mathrm{s}}$ & Frequency of the whole sample \\
\hline $\mathrm{f}_{\mathrm{tt}}$ & Total frequency \\
\hline
\end{tabular}

\subsection{Opinions on STEM Education}

In this section, a question was asked to all participants to identify their level of having the knowledge related to STEM education. Three more questions were asked to the ones who answered the question as "yes" or "partly" while for the ones who answered the question as "no", other questions were asked. The findings from these questions were described under for headings.

\subsubsection{The State of Having Knowledge about "STEM Education" by Lecturers, Teachers and Pre-service Teachers}

The lecturers, teachers and pre-service teachers were asked if they have ever heard of the term STEM education. The participants answered this question as "yes", "partly" or "no". 


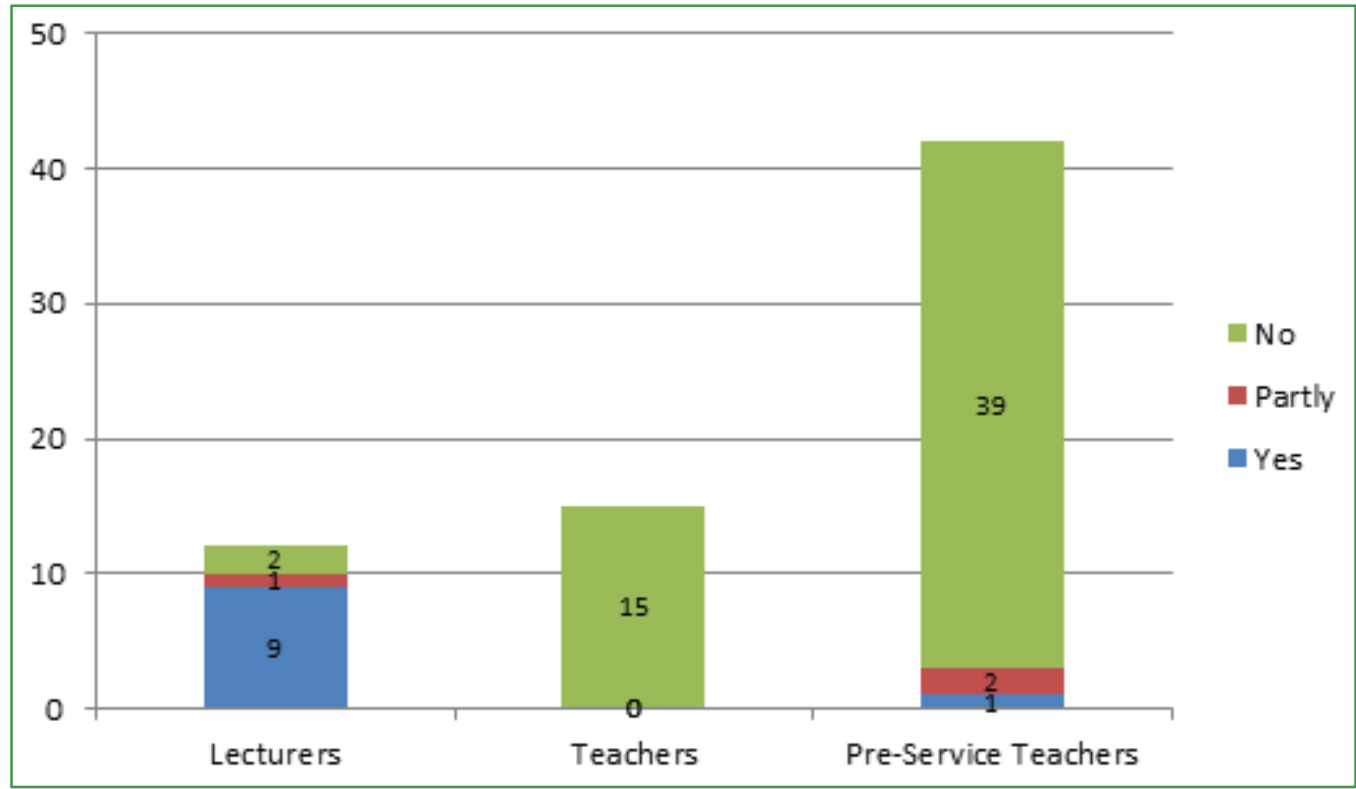

Figure 1. The state of having knowledge about STEM education by lecturers, teachers and pre-service teachers

9 of the lecturers responded to the this question as "yes", 1 of them answered "partly" and 2 of them answered "no". The ones whose responses were "partly" and "no" work at the faculty of engineering. It was found that only very few of the pre-service teachers $(\mathrm{f}=3)$ had some knowledge about STEM education while teachers did not know about this approach.

\subsubsection{The Resources from Which the Lecturers, Teachers} and Pre-service Teachers Learned the Term "STEM Education"

The lecturers, teachers and pre-service teachers were asked if they have ever heard of the term STEM education and if yes, from which resource they heard the term. According to the answers given by lecturers, the themes of "advisory process", "following the literature" and "other" were created. From the pre-service teachers" answers, themes that were created were "undergraduate courses" and "university activities".

Table 5. The resources from which the lecturers, teachers and pre-service teachers learned the term "STEM education"

\begin{tabular}{|c|c|c|c|c|}
\hline Sample & Theme & Code & $\mathrm{f}$ & $\mathrm{f}_{\mathrm{tt}}$ \\
\hline \multirow{3}{*}{ Lecturers } & $\begin{array}{l}\text { Advisory } \\
\text { Process }\end{array}$ & $\begin{array}{c}\text { 1. While facilitating for } \\
\text { the students to decide } \\
\text { on thesis subject }\end{array}$ & 6 & \multirow{3}{*}{10} \\
\hline & $\begin{array}{c}\text { Following the } \\
\text { Literature }\end{array}$ & $\begin{array}{c}\text { 2. While reviewing the } \\
\text { literature }\end{array}$ & 2 & \\
\hline & Other & $\begin{array}{c}\text { 3. Colleagues } \\
\text { (Academicians) } \\
\text { 4. Internet }\end{array}$ & $\begin{array}{l}1 \\
1\end{array}$ & \\
\hline Teachers & - & - & - & - \\
\hline \multirow{2}{*}{$\begin{array}{l}\text { Pre-service } \\
\text { teachers }\end{array}$} & $\begin{array}{c}\text { Undergraduate } \\
\text { courses }\end{array}$ & 5. in the classroom & 2 & \multirow[b]{2}{*}{3} \\
\hline & $\begin{array}{l}\text { University } \\
\text { activities }\end{array}$ & $\begin{array}{c}\text { 6. STEM \& Maker } \\
\text { Fest/Expo Organized by } \\
\text { Hacettepe University }\end{array}$ & 1 & \\
\hline Total & & & 13 & 13 \\
\hline
\end{tabular}

It was found that lecturers learned about STEM education in the advisory process during which they guide their students for their theses whereas the pre-service teachers learned about the term in the courses they took at university or in the activities that university organized. Similarly, Hacıoğlu, Yamak \& Kavak [38] stated that more than half of the teachers who participated in their study didn't have knowledge about STEM, and the ones who had some knowledge about the term learned it through the workshops, social media and academic studies.

\subsubsection{Definition of STEM Education}

Table 6. The Definitions of STEM Education by Lecturers, Teachers and Pre-Service teachers

\begin{tabular}{|c|c|c|c|c|}
\hline Sample & Theme & Code & $\mathrm{f}$ & $f_{t t}$ \\
\hline \multirow{3}{*}{ Lecturers } & \multirow{2}{*}{$\begin{array}{l}\text { The } \\
\text { integration } \\
\text { of } \\
\text { disciplines }\end{array}$} & $\begin{array}{l}\text { 1. An educational approach } \\
\text { based on the integration of } \\
\text { science, technology, } \\
\text { engineering and mathematics } \\
\text { with interdisciplinary approach }\end{array}$ & 6 & \multirow{3}{*}{9} \\
\hline & & $\begin{array}{l}\text { 2. An educational approach in } \\
\text { which science, technology, } \\
\text { engineering and mathematics } \\
\text { are integrated to find solutions } \\
\text { for the real world problems. }\end{array}$ & 2 & \\
\hline & $\begin{array}{c}\text { Evaluation } \\
\text { process }\end{array}$ & $\begin{array}{l}\text { 3. The evaluation of teaching } \\
\text { within the scope of pedagogy }\end{array}$ & 1 & \\
\hline Teachers & - & - & - & - \\
\hline \multirow{3}{*}{$\begin{array}{l}\text { Pre-service } \\
\text { teachers }\end{array}$} & \multirow{3}{*}{$\begin{array}{l}\text { The } \\
\text { integration } \\
\text { of Science } \\
\text { with other } \\
\text { STEM } \\
\text { disciplines }\end{array}$} & $\begin{array}{c}\text { 4. Teachers' integration of } \\
\text { other disciplines into their } \\
\text { classes by means of technology. }\end{array}$ & 1 & \multirow{3}{*}{3} \\
\hline & & $\begin{array}{c}\text { 5. Presenting the relationship } \\
\text { between science, technology } \\
\text { and mathematics. }\end{array}$ & 1 & \\
\hline & & $\begin{array}{l}\text { 6. the integration of science } \\
\text { subjects with other courses }\end{array}$ & 1 & \\
\hline Total & & & 12 & 12 \\
\hline
\end{tabular}


Lecturers, teachers and pre-service teachers were asked the question: "What is STEM education?". According to the responses, lecturers consider STEM is "the integration of disciplines", "evaluation process"; pre-service teachers consider that it is "the integration of Science with other STEM disciplines". Themes were formed according to the responses given by lecturers and pre-service teachers.

When the definitions were analyzed, it was found that STEM education was generally defined as "the integration of Science, Technology, Engineering and Mathematics". There is not a definition for STEM education which is accepted by everyone in the worldwide [81]. Breiner, Johnson, Harkness, Koehler [18] and Sanders [80] described this approach as the integration of different STEM disciplines to be able to solve real world problems. One of the definitions given by a participant is as follows:

L9 "STEM is an educational approach that is based on interdisciplinary instruction through the integration of science, technology, engineering and mathematics".

\subsubsection{The Characteristics of a STEM Teacher}

Lecturers, teachers and pre-service teachers were asked the question: "What are the characteristics that STEM teachers should have?". Twenty codes for the answers given were gathered under three themes that "the personal characteristics that STEM teachers should have", "The professional characteristics that STEM teachers should have" and "21st century skills that STEM teachers should have".

When the characteristics shown in Table 3 were analyzed, it was found that the theme about 21 st century skills had the highest frequency level $(\mathrm{f}=20)$. The frequency levels of other codes were as follows: "should have a command of his/her own STEM discipline and have the knowledge about similar disciplines" ( $\mathrm{f}=7$ ), "should be open to/curious about learning" ( $\mathrm{f}=6$ ), "should be able to use technology effectively" ( $\mathrm{f}=5)$, "should be open to collaborate" ( $\mathrm{f}=5)$, "should follow the recent developments about education" ( $\mathrm{f}=4)$. As the level of school success depends on the quality of the teachers and the teaching quality [39], the STEM teachers who would like to improve students at certain skills such as problem solving skills, creative thinking, critical thinking, decision making should also have some experience of these skills themselves [5, 24, $50,52,77,86,93]$. The code "having the skills to prepare and implement a lesson plan for STEM education" ( $\mathrm{f}=7$ ) is another high frequency level code. It has an important role in planning, guiding the teachers, making the learning more effective through in-class activities and reaching the instructional purposes [95]. The research in the related literature, it is stated that planning makes the learning process more purposeful and effective [53]. The characteristics that teachers should have will improve the quality of education as well. One of the Opinions on this subject is as follows:

L8 "A teacher who teaches in one of the STEM disciplines should have a certain level of other disciplines. In addition, this teacher should be open to improve himself/herself, be an eclectic teacher, and have a sufficient content and teaching knowledge and experience in his/her own field. STEM teachers cannot be trained only within or during undergraduate level. They should have content knowledge, professional teaching knowledge, field-related skills, technological skills, and the ability to design a constructive learning environment. To do this, they should have the required experience and they should know well about the philosophy and key elements of problem and project based learning".

Table 7. Lecturers, Teachers and Pre-service teachers' Opinions on the Characteristics that STEM Teachers Should Have

\begin{tabular}{|c|c|c|c|c|c|c|}
\hline Theme & Code & $\mathbf{f}_{\mathbf{l}}$ & $\mathbf{f}_{\mathrm{te}}$ & $\mathbf{f}_{\mathrm{pst}}$ & $\mathbf{f}_{\mathrm{s}}$ & $\mathbf{f}_{\mathrm{t}}$ \\
\hline \multirow{3}{*}{$\begin{array}{c}\text { The personal } \\
\text { characteristics } \\
\text { that STEM } \\
\text { teachers } \\
\text { should have }\end{array}$} & $\begin{array}{l}\text { 1. should be open to/curious about } \\
\text { learning }\end{array}$ & 5 & - & 1 & 6 & \multirow{3}{*}{13} \\
\hline & 2. should be open to collaborate & 5 & - & - & 5 & \\
\hline & 3. should view things holistically & 2 & - & - & 2 & \\
\hline \multirow{11}{*}{$\begin{array}{c}\text { The } \\
\text { professional } \\
\text { characteristics } \\
\text { that STEM } \\
\text { teachers } \\
\text { should have }\end{array}$} & $\begin{array}{l}\text { 4. should have the skills to prepare and } \\
\text { implement a lesson plan for STEM } \\
\text { education }\end{array}$ & 5 & - & 2 & 7 & \multirow{11}{*}{18} \\
\hline & $\begin{array}{l}\text { 5. should have a command of his/her } \\
\text { own STEM discipline and have the } \\
\text { knowledge about similar disciplines }\end{array}$ & 6 & - & 1 & 7 & \\
\hline & $\begin{array}{l}\text { 6. should follow the recent } \\
\text { developments about education }\end{array}$ & 3 & - & 1 & 4 & \\
\hline & $\begin{array}{l}\text { 7. should have a good pedagogical } \\
\text { knowledge }\end{array}$ & 3 & - & - & 3 & \\
\hline & $\begin{array}{l}\text { 8. should have a certain amount of } \\
\text { professional experience }\end{array}$ & 2 & - & - & 2 & \\
\hline & $\begin{array}{l}\text { 9. should have a high level of science } \\
\text { literacy }\end{array}$ & - & - & 1 & 1 & \\
\hline & $\begin{array}{l}\text { 10. should improve students' sense of } \\
\text { wonder }\end{array}$ & - & - & 1 & 1 & \\
\hline & $\begin{array}{l}\text { 11. should have the skills related to the } \\
\text { field }\end{array}$ & 1 & - & - & 1 & \\
\hline & $\begin{array}{l}\text { 12. should design a constructive } \\
\text { learning environment }\end{array}$ & 1 & - & - & 1 & \\
\hline & $\begin{array}{l}\text { 13. should know the basics of } \\
\text { problem-based and project-based } \\
\text { learning. }\end{array}$ & 1 & - & - & 1 & \\
\hline & $\begin{array}{l}\text { 14. should have an intermediate level of } \\
\text { knowledge in a foreign language. }\end{array}$ & 1 & - & - & 1 & \\
\hline \multirow{6}{*}{$\begin{array}{l}\text { 21st century } \\
\text { skills that } \\
\text { STEM } \\
\text { teachers } \\
\text { should have }\end{array}$} & 15. should be able to think creatively & 6 & - & 1 & 7 & \multirow{6}{*}{20} \\
\hline & $\begin{array}{l}\text { 16. should be able to use technology } \\
\text { effectively }\end{array}$ & 4 & - & 1 & 5 & \\
\hline & $\begin{array}{l}\text { 17. should be able to think within design } \\
\text { driven approach }\end{array}$ & 2 & - & - & 2 & \\
\hline & 18. should be able to think innovatively & 2 & - & - & 2 & \\
\hline & 19. should have an entrepreneurial spirit & 2 & - & - & 2 & \\
\hline & 20. should have problem solving skills & 2 & - & - & 2 & \\
\hline Total & & 53 & - & 9 & 62 & 62 \\
\hline
\end{tabular}

\subsubsection{Integrated Teaching Knowledge in the Teaching Profession}

The question that "What are your opinions on the acquisition of integrated teaching knowledge that includes co-teaching related fields such as science, technology, engineering (design) and mathematics in the teaching 
profession?" was asked to lecturers, teachers and pre-service teacher. Thirty codes for the answers given were gathered under two main themes nine sub-themes that The professional knowledge that the teacher should have", "The skills that the teacher should have", "The effect of integrated teaching knowledge on learning-teaching process", "The nature of science", "The deficiencies aspects of teachers in terms of professional ", "Structure of STEM fields", "The factors related to teacher", "Proposal", "Other".

While the full participation of teaching staff and teachers in the acquisition of integrated teaching knowledge is concerned, it seems that four of the prospective teachers are negative about acquiring this knowledge.

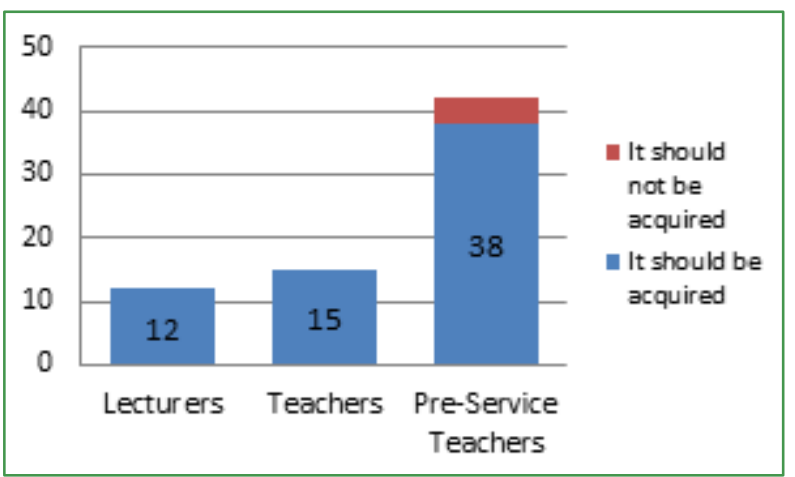

Figure 2. Opinions of Lecturers, Teachers and Pre-Service Teachers Regarding the Acquisition of the Integrated Teaching Knowledge to Teacher

Table 8. Opinions of Lecturers, Teachers and Pre-Service Teachers Regarding the Acquisition of Integrated Teaching Knowledge

\begin{tabular}{|c|c|c|c|c|c|c|c|}
\hline Theme & Sub-theme & Code & $\mathbf{f}_{\mathbf{I}}$ & $\mathbf{f}_{\mathbf{t}}$ & $\mathbf{f}_{\mathrm{pst}}$ & $\mathbf{f}_{\mathrm{s}}$ & $\mathbf{f}_{\mathrm{t}}$ \\
\hline \multirow{25}{*}{$\begin{array}{l}\text { The reasons for } \\
\text { Necessity of } \\
\text { Acquisition of } \\
\text { Integrated } \\
\text { Teaching } \\
\text { Knowledge }\end{array}$} & \multirow{5}{*}{$\begin{array}{c}\text { The professional } \\
\text { knowledge the } \\
\text { teacher should have }\end{array}$} & 1. Teachers should have knowledge of educational technologies & 7 & - & 8 & 15 & \multirow{5}{*}{55} \\
\hline & & 2. Teachers should have basic knowledge of related fields & 5 & - & 10 & 15 & \\
\hline & & 3. Teachers should have sufficient content knowledge & 12 & - & - & 12 & \\
\hline & & $\begin{array}{l}\text { 4. Teachers should have knowledge of the integration of different } \\
\text { disciplines since the undergraduate training }\end{array}$ & 8 & - & - & 8 & \\
\hline & & $\begin{array}{l}\text { 5. Teachers should have design (engineering) knowledge to embody } \\
\text { learned subject }\end{array}$ & - & - & 5 & 5 & \\
\hline & \multirow{4}{*}{$\begin{array}{c}\text { The skills the } \\
\text { teacher should have }\end{array}$} & 6. Teachers should be able to study interdisciplinary & 6 & - & - & 6 & \multirow{4}{*}{17} \\
\hline & & $\begin{array}{l}\text { 7. Teachers should know problem based and project based learning and } \\
\text { they should apply them in class }\end{array}$ & 5 & - & - & 5 & \\
\hline & & 8. Teachers should have 21 st century skills & 3 & - & - & 3 & \\
\hline & & $\begin{array}{l}\text { 9. Teachers should be able to design versatile and student-centered } \\
\text { activities }\end{array}$ & 3 & - & - & 3 & \\
\hline & \multirow{7}{*}{$\begin{array}{c}\text { The effect of } \\
\text { integrated teaching } \\
\text { knowledge on } \\
\text { learning-teaching } \\
\text { process }\end{array}$} & 10. Teacher effectively explains the subject & - & - & 15 & 15 & \multirow{7}{*}{32} \\
\hline & & 11. The teaching success of the teacher increases & - & 1 & 4 & 5 & \\
\hline & & 12. The student's academic achievement increases & - & 3 & 1 & 4 & \\
\hline & & 13. The achievement of students' projects increases & 3 & - & - & 3 & \\
\hline & & 14. It makes easier to attract students' attention & - & 2 & - & 2 & \\
\hline & & 15. The teacher improves him(her)self & - & - & 2 & 2 & \\
\hline & & 16. Current developments are associated with subjects & - & - & 1 & 1 & \\
\hline & \multirow{3}{*}{$\begin{array}{l}\text { The nature of } \\
\text { science }\end{array}$} & $\begin{array}{l}\begin{array}{l}\text { 17. The science course requires integrated teaching knowledge because } \\
\text { of it is related to other fields }\end{array} \\
\end{array}$ & - & 13 & - & 13 & \multirow{3}{*}{31} \\
\hline & & 18. Science needs advanced mathematical knowledge & - & - & 11 & 11 & \\
\hline & & 19. Science has an interdisciplinary structure in itself & - & - & 7 & 7 & \\
\hline & \multirow{5}{*}{$\begin{array}{c}\text { The deficiencies } \\
\text { aspects of teachers } \\
\text { in terms of } \\
\text { professional }\end{array}$} & 20. Teachers have insufficient knowledge of mathematics education & - & 8 & - & 8 & \multirow{5}{*}{27} \\
\hline & & 21. Teachers have insufficient integrated teaching knowledge & - & 7 & - & 7 & \\
\hline & & $\begin{array}{l}\text { 22. Teachers' background regarding design and project preparation is } \\
\text { insufficient }\end{array}$ & - & 5 & - & 5 & \\
\hline & & 23. The teachers' knowledge of educational technologies is insufficient & - & 4 & - & 4 & \\
\hline & & 24. Teachers need in service training on new approaches to education & - & 3 & - & 3 & \\
\hline & Proposal & $\begin{array}{l}\text { 25. Acquiring the integrated teaching knowledge at the postgraduate } \\
\text { education is more appropriate }\end{array}$ & 3 & - & - & 3 & 3 \\
\hline \multirow{5}{*}{$\begin{array}{c}\text { The reasons for } \\
\text { non-acquiring of } \\
\text { integrated } \\
\text { teaching } \\
\text { knowledge }\end{array}$} & $\begin{array}{l}\text { The structure of } \\
\text { STEM fields }\end{array}$ & $\begin{array}{l}\text { 26. Science, mathematics, design (engineering) courses have different } \\
\text { contents }\end{array}$ & - & - & 1 & 1 & \multirow{5}{*}{6} \\
\hline & \multirow{2}{*}{$\begin{array}{c}\text { The factors related } \\
\text { to teacher }\end{array}$} & 27. The content knowledge that the teacher should have will increase & - & - & 2 & \multirow[b]{2}{*}{3} & \\
\hline & & $\begin{array}{l}\text { 28. The preference of the occupation will reduce due to the content } \\
\text { knowledge that the teacher should have will increase }\end{array}$ & - & - & 1 & & \\
\hline & \multirow{2}{*}{ Other } & 29. STEM education is not suitable for our country & - & - & 1 & \multirow{2}{*}{2} & \\
\hline & & 30. Course hours will increase in case of integration of courses/fields & - & - & 1 & & \\
\hline & & Total & 55 & 46 & 70 & 171 & 171 \\
\hline
\end{tabular}


As regards acquiring integrated teaching knowledge, Participants generally indicated the professional knowledge that teachers should have and the effects of this knowledge on the learning-teaching process $(f=32)$. For examples, "Teachers should have knowledge of educational technologies" ( $f=15)$, "Teachers should have sufficient content knowledge" ( $f=12)$ and "Teachers should have basic knowledge of related disciplines" ( $f=$ 15). According to the findings in this article, the science teachers feel themselves incapable of their knowledge of mathematics education. This finding gives a clue as to why they think they are inadequate regarding integration. On the other hand, according to the interdisciplinary nature of science, integrated teaching knowledge must be taught to teachers.

Science, mathematics and technology have been identified as the most suitable areas to integrate in terms of scientific approaches and application areas used in problem solving [88]. In recent years, an interdisciplinary approach has been preferred in integrating disciplines. Since this approach positively influenced learning by helping explain the scientific events in integrity, it began to dominate the idea that integration should be done in the teaching of science [36]. The use of technology by teachers through the reflection of technology and the integration of science into mathematics bring with academic success $[2,35,37,52,56$, 85]. For this reason, it is expected that STEM teachers, who will apply the integrated education approach, have the knowledge and skill to integrate different disciplines. In addition, it is seen that in Table 4 some lecturers $(f=3)$ have the opinion that this knowledge should be acquired in postgraduate education, not in undergraduate education. In the interviews, these persons stated that the STEM teacher should have the knowledge and skills related to other STEM fields after his own STEM field. Participants' opinions in this regard are as follows:

L2: "When the current curricula are examined, it can be considered that this knowledge is acquired. But in practice it is not. Teaching science and mathematics are dealt with separate in practice. I advocate that the integration of science and mathematics should be acquired. In daily life, a problem does not appear as a science problem, a technology problem, or a mathematical problem. ... Besides these, I consider that art, aesthetics, moral courses should also be in the program."

PST2: "While the teacher is teaching, he must integrate science, technology, engineering and mathematics fields. This knowledge must be taught to the teachers as the teacher should show to students the relations between the fields."

TE3: "I believe that teachers should have this knowledge. I think I have the knowledge of science and mathematics.
But, sometimes I have trouble integrating them together. ... Designing a project, we need design knowledge. The integrative teaching knowledge is even more necessary when studying on the project or product. Otherwise, there is only one discipline in project."

When the opinions of the participants are examined, it is seen that the courses the STEM fields-related are given separately in the teacher education programs and no efforts are made to integrate these areas and hence integrated teaching knowledge are not acquired to pre-service teacher. To be able to train individuals who are aware of real life problems (covering different areas) and who can produce alternative solutions to problems, teachers need to have knowledge and skills related to these areas and reflect the whole point of view to their students. For that reason, studies to acquire this knowledge to teachers should be started from undergraduate education.

The increase in knowledge the teacher should have ( $f$ $=2$ ) leads to negative thinking of the pre-service teacher about acquiring the integrated teaching knowledge.

\subsubsection{Teacher Education Programs in Acquiring Integrated Teaching Knowledge}

The question "Do courses in teacher education programs aimed to acquire integrated teaching knowledge to pre-service teacher? Explain your answer with reasons." was asked to lecturers, teachers and pre-service teachers. The codes and themes determined according to the answers given are demonstrated in three tables.

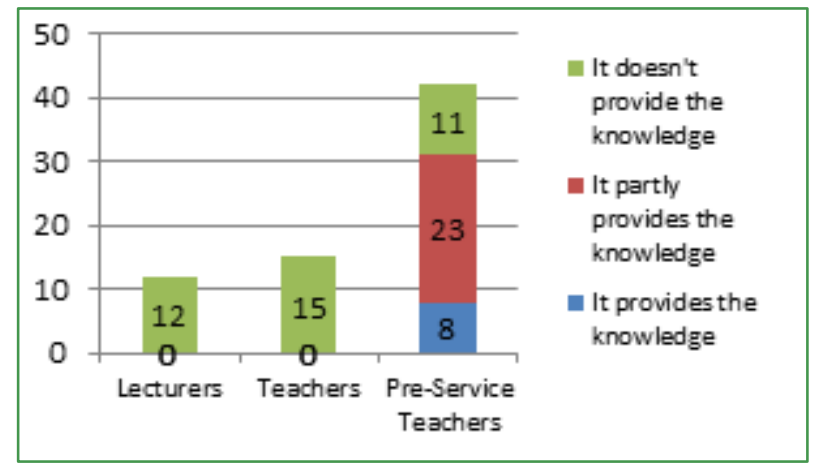

Figure 3. Opinions of Lecturers, Teachers and Pre-Service Teachers Regarding the Level of Acquiring Integrated Teacher Knowledge of Teacher education programs to Pre-Service Teacher

Lecturer and teachers agree that teacher education programs do not provide integrated teaching knowledge to pre-service teacher. More than half of the pre-service teachers $(f=23)$ consider that this knowledge is partly acquired, and some of them $(f=8)$ consider this knowledge is fully acquired. 
Table 9. Opinions of Lecturers, Teachers and Pre-Service Teachers Regarding the Reasons for the Courses in Teacher Education Programs Not Providing Integrated Teaching Knowledge to Pre-Service Teacher

\begin{tabular}{|c|c|c|c|c|c|c|}
\hline Theme & Code & $\mathrm{f}_{\mathrm{l}}$ & $\mathrm{f}_{\mathrm{t}}$ & $\mathrm{f}_{\mathrm{pst}}$ & $\mathrm{f}_{\mathrm{s}}$ & $f_{t}$ \\
\hline \multirow{7}{*}{$\begin{array}{l}\text { The reasons } \\
\text { arising from the } \\
\text { undergraduate } \\
\text { program }\end{array}$} & $\begin{array}{l}\text { 1. There is no course that aimed to integrate different fields in teacher education } \\
\text { programs }\end{array}$ & 12 & 12 & - & 24 & \multirow{7}{*}{63} \\
\hline & 2. The teacher education programs is not suitable for integrating the fields & 8 & - & - & 8 & \\
\hline & $\begin{array}{l}\text { 3. Content knowledge and pedagogical content knowledge courses are independent } \\
\text { of each other }\end{array}$ & 8 & - & 6 & 14 & \\
\hline & 4. Providing content knowledge courses separately & - & - & 5 & 5 & \\
\hline & 5. No study for integrating different fields in courses & - & - & 5 & 5 & \\
\hline & 6. Not providing sufficient knowledge of Mathematics education & - & - & 4 & 4 & \\
\hline & 7. No courses on project preparation and design & - & 3 & - & 3 & \\
\hline \multirow{4}{*}{$\begin{array}{c}\text { The reasons } \\
\text { arising from } \\
\text { learning-teaching } \\
\text { process }\end{array}$} & 8. Courses are usually theoretical processing and not involve practice & 8 & 12 & - & 20 & \multirow{4}{*}{26} \\
\hline & 9. The content of course is at the discretion of the lecturer & 3 & - & - & 3 & \\
\hline & 10. It is that there are same lecturers in courses & - & 1 & - & 1 & \\
\hline & $\begin{array}{l}\text { 11. Not providing sufficient knowledge about the practices of different and new } \\
\text { teaching methods }\end{array}$ & - & - & 2 & 2 & \\
\hline \multicolumn{2}{|r|}{ Total } & 39 & 28 & 22 & 89 & 89 \\
\hline
\end{tabular}

Participants reported the opinions that "There is no course that aimed to integrate different fields in teacher education programs" ( $\mathrm{f}=24)$, "Courses are usually theoretical processing and not contain practice" $(\mathrm{f}=20)$, "Content knowledge and pedagogical content knowledge courses are independent of each other" ( $\mathrm{f}=14)$ " and "The teacher education programs is not suitable for integrating the fields" as reasons why integrated teaching knowledge is not acquired in teacher education programs. It is seen that the undergraduate programs $(\mathrm{f}=63)$ is at the beginning of the obstacles to acquiring this knowledge.

There are the multidisciplinary approach and integrated program at the basis of STEM education, so teacher education programs need to be designed to include them. Pre-service teachers who have graduated from undergraduate programs that have not contained integrating different disciplines will encounter problems in the implementation process of STEM education and will fail. This situation with regards to the undergraduate programs of the Education Faculties will also limit the studies in relation to STEM education. Berlin and White [16] reported that integrated teacher education programs contribute to the pre-service teachers realize the difficulties in the integration of science, mathematics and technology. Some of the participants' opinions are as follows:

PST6: "No knowledge is acquired about the integrated courses as our courses are only relevant to science teacher.

L4: "The current program includes courses aimed at teaching these four areas separately. Maybe we can say that mathematics and technology are integrated, but it is very weak to associate with other disciplines. Since the courses focus on theoretical and one discipline, the integrated teaching knowledge isn't acquired to pre-service teacher in the courses."

TE10: "The names and contents of the courses seem to be aimed at providing integrated teaching knowledge.
However, knowledge on integration is not given in practice. Although the practice provides the opportunity to integrate different disciplines, there is no practice in courses."

Participants generally emphasize that no studies have been done to integrate different fields in courses in undergraduate programs and no knowledge has been provided in this regard. Implementation of STEM education is very difficult in places where integration and interdisciplinary work are not available.

Table 10. Opinions of Pre-Service Teachers Regarding the Reasons for the Courses in Teacher Education Programs Partially Providing Integrated Teaching Knowledge to Pre-Service Teacher

\begin{tabular}{|c|c|c|c|c|}
\hline \multicolumn{2}{|c|}{ Theme } & Code & $f_{p s t}$ & $f_{t}$ \\
\hline \multirow{5}{*}{$\begin{array}{c}\text { The reasons } \\
\text { arising from } \\
\text { undergraduate } \\
\text { program }\end{array}$} & \multirow{4}{*}{$\begin{array}{l}\text { Negative } \\
\text { reasons }\end{array}$} & $\begin{array}{c}\text { 1. Giving inadequate } \\
\text { knowledge of mathematics } \\
\text { education }\end{array}$ & 6 & \multirow{5}{*}{20} \\
\hline & & $\begin{array}{l}\text { 2. Not being sufficient } \\
\text { courses related to } \\
\text { educational technology }\end{array}$ & 4 & \\
\hline & & $\begin{array}{c}\text { 3. It is that Courses of } \\
\text { Content Knowledge is } \\
\text { separate }\end{array}$ & 2 & \\
\hline & & $\begin{array}{c}\text { 4. Concentration of the } \\
\text { given education heavily in } \\
\text { the field of science }\end{array}$ & 2 & \\
\hline & $\begin{array}{l}\text { Positive } \\
\text { reasons }\end{array}$ & $\begin{array}{l}\text { 5. There are courses related } \\
\text { to mathematics and } \\
\text { computers besides science } \\
\text { in the program }\end{array}$ & 6 & \\
\hline \multirow{3}{*}{\multicolumn{2}{|c|}{$\begin{array}{l}\text { The reasons arising from } \\
\text { learning-teaching process }\end{array}$}} & $\begin{array}{c}\text { 6. The courses, except } \\
\text { laboratory courses, are } \\
\text { theoritical rather than } \\
\text { practical }\end{array}$ & 5 & \multirow{3}{*}{11} \\
\hline & & $\begin{array}{c}\text { 7. Often to integrate } \\
\text { different fields in elective } \\
\text { courses }\end{array}$ & 3 & \\
\hline & & \begin{tabular}{|c|}
$\begin{array}{l}\text { 8. Course processing with } \\
\text { the standardized methods } \\
\text { of the lecturers }\end{array}$ \\
\end{tabular} & 3 & \\
\hline \multicolumn{3}{|c|}{ Total } & 31 & 31 \\
\hline
\end{tabular}


It has been shown that "Providing inadequate knowledge of mathematics education" ( $\mathrm{f}=6$ ) and "Not being sufficient courses in educational technology" ( $\mathrm{f}=4$ ) as a negative reasons of partial gaining of integrated teaching knowledge. "There are courses related to mathematics and computers besides science in the program" ( $\mathrm{f}=6)$ has been shown as a positive reason. Findings show that students have different perspectives on the courses they have taken. Negative reasons that caused from the program were mentioned earlier in Table 4 as a requirement for teachers to acquire integrated teaching knowledge. Some students consider that mathematics and education technology courses they have taken independently of science courses will be sufficient for integration while others consider the opposite.

Pre-service teachers said that "there are courses related to mathematics and computers besides science in the program" ( $\mathrm{f}=3$ ), "Laboratory courses offer the possibility to integrate different fields" ( $\mathrm{f}=3$ ) and "the content of the courses in the program is related to each other" ( $\mathrm{f}=3)$ as a reason to be acquired integrated teaching knowledge in teacher education programs knowledge. Findings in this table are similar to Table 6. Findings indicate that pre-service teachers consider that having knowledge about different fields is enough to integrate these fields. However, in order students to be able to integrate the fields, they need theoretical knowledge about the interdisciplinary approach and integrated programs and courses to transform this knowledge into practice.
Table 11. Pre-service Teacher's Opinions about the Reasons for Teacher Education Programs Gaining Integrated Teacher Knowledge to Pre-service teacher

\begin{tabular}{|c|c|c|c|}
\hline Theme & Code & $\mathbf{f}_{\mathrm{pst}}$ & $\mathbf{f}_{\mathbf{t}}$ \\
\hline \multirow{4}{*}{$\begin{array}{l}\text { The reasons } \\
\text { arising from } \\
\text { undergraduate } \\
\text { program }\end{array}$} & $\begin{array}{l}\text { 1. Being courses related to } \\
\text { mathematics and computers } \\
\text { besides science in the program }\end{array}$ & 3 & \multirow{4}{*}{10} \\
\hline & $\begin{array}{l}\text { 2. the content of the courses in the } \\
\text { program is related to each other }\end{array}$ & 3 & \\
\hline & $\begin{array}{c}\text { 3. Laboratory courses offer the } \\
\text { possibility to integrate different } \\
\text { fields }\end{array}$ & 3 & \\
\hline & $\begin{array}{c}\text { 4. Pedagogical knowledge courses } \\
\text { contribute to integrating different } \\
\text { fields }\end{array}$ & 1 & \\
\hline $\begin{array}{l}\text { Reasons arising } \\
\text { from } \\
\text { learning-teaching } \\
\text { process } \\
\end{array}$ & $\begin{array}{l}\text { 5. Methods and techniques used by } \\
\text { lecturers }\end{array}$ & 1 & 1 \\
\hline \multicolumn{2}{|r|}{ Total } & 11 & 11 \\
\hline
\end{tabular}

\subsection{The proposals for Teacher Education Programs}

The question "Should there be a separate course (course) for acquiring integrated teaching knowledge in teacher education programs? What are your proposals for this program?" was asked to lecturers and teachers. Twelve codes related to the answers given were gathered under three themes: "Proposals for STEM education", "Proposals for program", "Proposals for the learning-teaching process of the program".

Table 12. Proposals of Lecturers and Teachers for Teacher Education programs

\begin{tabular}{|c|c|c|c|c|c|}
\hline Theme & Code & $\mathrm{f}_{\mathrm{l}}$ & $\mathrm{f}_{\mathrm{te}}$ & $\mathrm{f}_{\mathrm{s}}$ & $\mathrm{f}_{\mathrm{t}}$ \\
\hline \multirow{3}{*}{$\begin{array}{l}\text { Proposals for STEM } \\
\text { education }\end{array}$} & 1. A separate course (program) should be & 7 & 10 & 17 & \multirow{3}{*}{27} \\
\hline & 2. Education on STEM should be given in postgraduate education & 3 & 5 & 8 & \\
\hline & $\begin{array}{l}\text { 3. Contents of all courses should be prepared to acquire integrated teaching } \\
\text { knowledge }\end{array}$ & 2 & - & 2 & \\
\hline \multirow{5}{*}{$\begin{array}{c}\text { Proposals for } \\
\text { undergraduate } \\
\text { program }\end{array}$} & 4. Practice-based activities pre-service teachers are active should be designed & 9 & 9 & 18 & \multirow{5}{*}{46} \\
\hline & 5. Activities that show teachers how to integrate different fields should be designed & 5 & 10 & 15 & \\
\hline & 6. Knowledge of mathematics education should be provided & - & 7 & 7 & \\
\hline & 7. Needs analysis should be done before the program is prepared & 3 & - & 3 & \\
\hline & 8. Project based learning should be & - & 3 & 3 & \\
\hline \multirow{4}{*}{$\begin{array}{c}\text { Proposals for } \\
\text { learning-teaching } \\
\text { process of program }\end{array}$} & $\begin{array}{l}\text { 9. The students should collaborate with students in different departments (related to } \\
\text { STEM fields) }\end{array}$ & 3 & 6 & 9 & \multirow{4}{*}{19} \\
\hline & $\begin{array}{l}\text { 10. Pre-service teachers should prepare an activity or course plan appropriate to } \\
\text { STEM education }\end{array}$ & 5 & - & 5 & \\
\hline & 11. Educational technologies should be used & - & 3 & 3 & \\
\hline & 12. Lecturers from different departments should attend to courses & 2 & - & 2 & \\
\hline \multicolumn{2}{|r|}{ Total } & 39 & 53 & 92 & 92 \\
\hline
\end{tabular}


While most of the lecturers and teachers commented that a course on STEM education should be given in teacher education programs $(f=17)$, some of them stated that Education on STEM should be given in postgraduate education $(f=8)$ should be given. It was suggested that the program should have activities based on the application where the students are active ( $f=18$ ) and show the integrationing of different fields $(f=15)$. Aslan Tutak, Akaygün and Tezsezen [9], Akaygün and Aslan Tutak [1], Çorlu, Capraro and Capraro [23] stated that this approach should be included in teacher education programs so that STEM education can be implemented effectively in schools as a result of their studies. Some of the proposals of lecturer and teachers are as follows:

L5: "The pre-service teacher must integrate his/her course in different fields so that he/she can develop his/her versatility and explain the subject better. ... Applications should be made showing how to integrate different fields. The project-based learning process is very suitable for STEM so it should be learned. Lecturers from different fields should attend the classes."

TE4: "It should be a intricate course that combines mathematics, science and technology. Both a theoretical and practical education should be given. Practical studies should be done on how to teach science and mathematics together."

\subsection{The situation of Lecturers Regarding Having Integrated Teaching Knowledge}

The question "Do you think that you have integrated teaching knowledge? Explain your answer with the reasons." was asked to lecturers. The three codes identified from the answers given are gathered under the theme "Reasons for having integrated teaching knowledge".

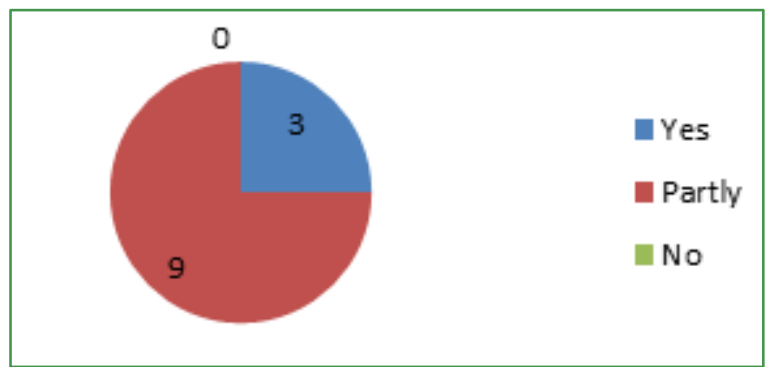

Figure 4. Opinions of the Lecturers Regarding Having Integrated Teaching Knowledge

Table 13. Reasons for Opinions of Lecturers

\begin{tabular}{|c|c|c|}
\hline Theme & Code & $\mathbf{f}_{\mathbf{l}}$ \\
\hline \multirow{2}{*}{$\begin{array}{c}\text { Reasons for having } \\
\text { integrated teaching } \\
\text { knowledge }\end{array}$} & $\begin{array}{c}\text { 1. Studying interdisciplinary due } \\
\text { to the department }\end{array}$ & 9 \\
\cline { 2 - 3 } & $\begin{array}{c}\text { 2. Self-improvement on fields } \\
\text { related to own field }\end{array}$ & 6 \\
\cline { 2 - 3 } & $\begin{array}{c}\text { 3. Being satisfied because of the } \\
\text { trainings }\end{array}$ & 3 \\
\hline & Total & 18 \\
\hline
\end{tabular}

The Lecturers consider that they have partly the integrated teaching knowledge because of developing themselves in fields related to own fields and the departments they are working on. They also pointed out that as it is very difficult to have in-depth knowledge of all fields, this knowledge is not acquired completely. Only the lecturers of engineering faculty answered yes to the question in this section. The opinions of a Lecturer about having integrated teaching knowledge are as follows:

L8: "My science and mathematics content knowledge were good because of my graduation field. I think I have partly integrated teaching knowledge because we need to integrate these areas with technology and design."

\subsection{The Science Teachers' Collaboration with Teachers that Teach Other Courses}

Table 14. Opinions of The Teachers on the Collaboration with the Teachers that teach Other Courses

\begin{tabular}{|c|c|c|c|c|}
\hline \multicolumn{2}{|c|}{ Theme } & Code & $\mathbf{f}_{\mathrm{te}}$ & $\mathbf{f}_{\mathbf{t}}$ \\
\hline \multicolumn{2}{|c|}{$\begin{array}{c}\text { Opinions about the cooperation } \\
\text { between the teachers }\end{array}$} & $\begin{array}{l}\text { 1. Cooperation between the } \\
\text { teachers is necessary }\end{array}$ & 13 & 13 \\
\hline \multirow{8}{*}{$\begin{array}{c}\text { Factors } \\
\text { facilitating } \\
\text { cooperation }\end{array}$} & \multirow{5}{*}{$\begin{array}{c}\text { Teacher } \\
\text { characteristics }\end{array}$} & $\begin{array}{l}\text { 2. Being open to } \\
\text { communication }\end{array}$ & 13 & \multirow{5}{*}{32} \\
\hline & & $\begin{array}{l}\text { 3. Having good content } \\
\text { knowledge }\end{array}$ & 8 & \\
\hline & & $\begin{array}{l}\text { 4. Teacher's personal } \\
\text { characteristics }\end{array}$ & 7 & \\
\hline & & $\begin{array}{l}\text { 5. Being that teachers open } \\
\text { to learning }\end{array}$ & 3 & \\
\hline & & $\begin{array}{c}\text { 6. Teachers in other } \\
\text { disciplines deal with science }\end{array}$ & 1 & \\
\hline & \multirow{3}{*}{ Other factors } & 7. School environment & 1 & \multirow{3}{*}{3} \\
\hline & & $\begin{array}{l}\text { 8. Parallel progress of the } \\
\text { curriculum of the other } \\
\text { courses with the science } \\
\text { course }\end{array}$ & 1 & \\
\hline & & $\begin{array}{l}\text { 9. Entering classes at the } \\
\text { same grade level as other } \\
\text { teachers }\end{array}$ & 1 & \\
\hline \multirow{12}{*}{$\begin{array}{l}\text { Contribution } \\
\text { of the } \\
\text { cooperation } \\
\text { to the course }\end{array}$} & \multirow{4}{*}{$\begin{array}{c}\text { Contribution to } \\
\text { learning-teaching } \\
\text { process }\end{array}$} & $\begin{array}{l}\text { 10. It affects the quality of } \\
\text { teaching positively }\end{array}$ & 9 & \multirow{4}{*}{19} \\
\hline & & $\begin{array}{l}\text { 11. It affects learning } \\
\text { positively }\end{array}$ & 6 & \\
\hline & & $\begin{array}{l}\text { 12. The success of the } \\
\text { science course increases }\end{array}$ & 3 & \\
\hline & & $\begin{array}{l}\text { 13. time is gained in } \\
\text { teaching time }\end{array}$ & 1 & \\
\hline & \multirow{6}{*}{$\begin{array}{l}\text { Contribution to } \\
\text { student }\end{array}$} & $\begin{array}{l}\text { 14. The academic } \\
\text { achievement of the student } \\
\text { increases }\end{array}$ & 11 & \multirow{6}{*}{29} \\
\hline & & $\begin{array}{l}\text { 15. The attitude / interest } \\
\text { towards the course of the } \\
\text { student increases }\end{array}$ & 8 & \\
\hline & & $\begin{array}{l}\text { 16. The deficiency in the } \\
\text { knowledge of students is } \\
\text { completed }\end{array}$ & 4 & \\
\hline & & $\begin{array}{l}\text { 17. The creativity of the } \\
\text { student develops }\end{array}$ & 3 & \\
\hline & & $\begin{array}{l}\text { 18. The student acquires } \\
\text { different perspectives }\end{array}$ & 2 & \\
\hline & & $\begin{array}{l}\text { 19. The student associates } \\
\text { the subject with daily life }\end{array}$ & 1 & \\
\hline & \multirow{2}{*}{$\begin{array}{l}\text { Contribution to } \\
\text { teacher }\end{array}$} & $\begin{array}{l}\text { 20. It contributes to the } \\
\text { teacher's professional } \\
\text { development }\end{array}$ & 11 & \multirow{2}{*}{12} \\
\hline & & $\begin{array}{l}\text { 21. The teacher has the } \\
\text { opportunity to complete the } \\
\text { deficiencies }\end{array}$ & 1 & \\
\hline & Total & & 108 & 108 \\
\hline
\end{tabular}


As a main question that "What do you think about cooperating with the teachers of other courses while you are teaching?"; as sub-questions that "What are the factors that make cooperation easier? What is the contribution of the collaboration to the functioning of your course?" were asked to teachers. The twenty codes that are determined regarding the answers given are gathered under the three main themes that "Opinions about the cooperation between the teachers", "Factors facilitating cooperation", "Contribution of the cooperation to the course" and the five sub-themes that "Teacher characteristics", "Other factors", "Contribution to learning-teaching process ", "Contribution to student ", "Contribution to teacher".

Table 10 is examined it appears that most of the teachers $(f=13)$ consider cooperation is necessary. This data is an important finding to increase cooperation in schools. According to the teachers, the most important factor facilitating cooperation is being to open communication ( $f$ $=13)$. In addition, Being that teachers' content knowledge is sufficient $(f=8)$ and personal characteristics $(f=7)$ are the other important factors to increase cooperation. Teachers consider that the collaboration will contribute to the student more than teachers $(f=29)$, and this contribution will be seen more in the student's academic achievement and attitude towards the course. It will contribute/contributes to the teachers to maintain his / her professional development. These findings are of great importance for increasing the quality of science teaching. However, some studies demonstrate that the communication of teachers with other teachers is limited [1]. Karakuş, Turhan Türkkan and Karakuş [57] have pointed out that the limited interaction is one of the most important reasons why teachers do not cooperate. Teachers who will acquire this skill to their students should firstly experience the learning environments based on cooperation [1]. Thus, the pupils of these teachers may be more advantageous in improving these skills. Some of the teachers' opinions on co-operation are as follows:

TE1 "I think it is necessary to cooperate with the teachers of other disciplines. In particular, cooperation with the mathematics teacher is contributing to the correct and complete process of the course."

\section{The Courses that the Science Teachers Associate with Their Own Course}

The question "Which courses do you associate with your course when you are teaching?" was asked to the teachers. The courses indicated according to the answers given by the teachers are demonstrated in the graphic.

When the courses related to science are examined, Mathematics $(f=15)$, which all teachers agree with, and ICT courses $(f=9)$ take attention. Also Karakuş, Turhan Turkkan and Karakuş [57] have found that science teachers associate their courses with mathematics course. Proposals to teacher education programs about these fields support the findings in Figure 5.

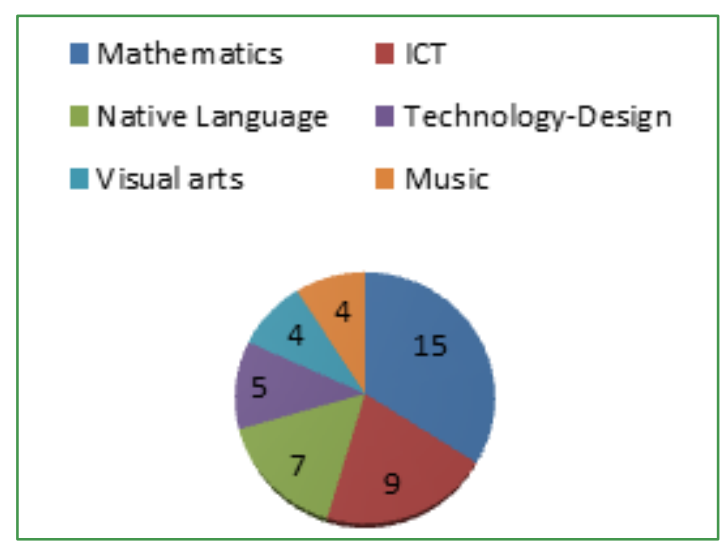

Figure 5. Courses Associated with the Science Course

\section{The Factors that Cause Problem for Teachers in Associating Their Course with Other Courses}

The question "What are the factors that cause problem for you in associating your course with other courses?" was asked to teachers. The ten codes determined from the answers given were gathered under four themes: "Student centered factors", "Teacher centered factors", "Program centered factors" and "Other".

Table 15. Opinions of Teachers on the Factors that Affect the Process of Integrating Science Course with the Different Courses

\begin{tabular}{|c|c|c|c|}
\hline Theme & Code & $\mathbf{f}_{\mathrm{t}}$ & $\mathbf{f}_{\mathbf{t}}$ \\
\hline \multirow{2}{*}{$\begin{array}{l}\text { Student centered } \\
\text { factors }\end{array}$} & $\begin{array}{c}\text { 1. Deficiencies in } \\
\text { foreknowledge of the students }\end{array}$ & 5 & \multirow{2}{*}{7} \\
\hline & $\begin{array}{l}\text { 2. Being low level readiness of } \\
\text { students }\end{array}$ & 2 & \\
\hline \multirow{6}{*}{$\begin{array}{l}\text { Teacher centered } \\
\text { factors }\end{array}$} & $\begin{array}{l}\text { 3. Lack of teacher's knowledge } \\
\text { in educational technologies }\end{array}$ & 9 & \multirow{6}{*}{25} \\
\hline & $\begin{array}{l}\text { 4. Lack of teacher's knowledge } \\
\text { in mathematics education }\end{array}$ & 8 & \\
\hline & $\begin{array}{l}\text { 5. Lack of teacher's knowledge } \\
\text { of project preparation and } \\
\text { design }\end{array}$ & 3 & \\
\hline & $\begin{array}{l}\text { 6. Teacher's undergraduate } \\
\text { education type }\end{array}$ & 3 & \\
\hline & $\begin{array}{l}\text { 7. Teacher's personal } \\
\text { characteristics }\end{array}$ & 1 & \\
\hline & $\begin{array}{l}\text { 8. Lack of application-based } \\
\text { activity management skill }\end{array}$ & 1 & \\
\hline $\begin{array}{l}\text { Program centered } \\
\text { factors }\end{array}$ & $\begin{array}{l}\text { 9. Curriculums are not suitable } \\
\text { for interdisciplinary approach }\end{array}$ & 2 & 2 \\
\hline Other & $\begin{array}{l}\text { 10. No problems in } \\
\text { interdisciplinary study }\end{array}$ & 1 & 1 \\
\hline Total & & 35 & 35 \\
\hline
\end{tabular}

It was found that the most important factors that make teachers difficult in the interdisciplinary course are 
teacher-originated $(\mathrm{f}=25)$ and as in Table 4 , it is seen that mathematics education and education technologies (ICT) are expressed again. This finding reveals that science teachers' knowledge are lacking in these fields. In addition, there is a lack of foreknowledge of students $(f=5)$ and the fact that the curriculums are not suitable for interdisciplinary approach $(f=2)$ are among the other factors that force teachers. Başkan, Alev and Kural [13] also demonstrate that teachers do not have sufficient background to do the integration of science and mathematics even though they find the interdisciplinary studies useful. Although teachers want to apply the interdisciplinary approach in their courses, they cannot apply this approach in their classes because they do not have sufficient knowledge and skills in other fields. Some of the teachers' opinions on the factors that challenge them are:

TE8: "I have the content knowledge of mathematics, but I think that I am inadequate in the teaching of some mathematical subjects in the science. Recently, technology has begun to gain importance in science course. That's why teachers need to have the knowledge to integrate science and technology."

\section{Conclusions}

The results of this research can be summarized as follows:

It was determined that although most of the lecturers have knowledge about STEM education, none of the teachers and majority of the pre-service teachers do not know this approach. While lecturers usually learn STEM education in the thesis process of their students, pre-service teachers learn STEM education in activities prepared by universities or in course.

STEM education [81], which does not have a globally recognized definition, is generally described by participants as "integrating science, technology, engineering and mathematics."

It has been determined that participants expect from STEM teachers to have the features such as creative thinking, ability to use technology, collaboration, be open to learning, be have a knowledge of fields related to own field, be mastery of own STEM field and following-up developments in education. It is also stated that STEM teachers should have the knowledge and skills to prepare and implement the course plan appropriate for STEM education.

Participants stated that integrated teaching knowledge should be acquired to teachers because of the fact that teachers should have knowledge about educational technologies, content knowledge, and basic knowledge about the other STEM fields and that science is in the interdisciplinary structure. On the other hand, the increase of the knowledge, which the teacher should have, caused some pre-service teachers to consider negatively about the acquisition of this knowledge.

It has been resulted that integrated teaching knowledge is not provided to the pre-service teachers. According to the participants, teacher education programs do not have a course to integrate different fields because of the structure of program that there are no activities to integrate different fields in the courses, that the programs is not suitable for integrating the fields, and that courses are theoretically processed. For this reason, teaching staff and teachers suggested that students should be active in Teacher Education Program and there should be a course related to the STEM education in which the efforts to integrate the different fields are carried out. Some participants stated that knowledge and skills related to STEM education should be provided at the graduate education.

It has been determined that most of the lecturer has partly integrated teaching knowledge due to their department and they develop themselves in the other STEM fields. Lecturers have stated that it is not possible to have full knowledge of this knowledge as it would be very difficult to have in-depth knowledge of all fields.

It has been determined that most of the teachers believe that cooperation is necessary. According to these teachers being open to communication is the most important factor to facilitate cooperation. Besides, being that teachers' content knowledge is sufficient and teacher's personal characteristics are the other important factors to increase cooperation. Teachers believe that the collaborative study will contribute to student much from teacher. This contribution will be seen in the student's academic achievement and attitude towards the course; and the collaboration will contribute to the maintenance of professional development of the teacher. This result is of great importance for the establishment of professional learning communities in schools.

It has been determined that science teachers associate their courses with mathematics and technology courses. It has been determined that the teacher's lack of knowledge of mathematics education and educational technology is the most challenging factor in the course study with the interdisciplinary approach. Other factors that force teachers are curriculums unsuitable for interdisciplinary approach and deficient in readiness of students.

When the results obtained from the study are examined; it has been determined that there are no courses related to STEM education and that the knowledge and skills necessary for the pre-service teacher to apply this approach in their professional lives have not been acquired. In addition, It was also found that the teachers integrated their courses mostly with mathematics and ICT, and that the teacher centered factors impede the course processing with the interdisciplinary approach, and that most of the teachers consider that cooperation among the teachers was necessary.

The increasing importance of STEM fields, the increase 
need for individuals with knowledge and skills in these fields, and the adaptation policies to Industry 4.0 transformation have further increased the importance given to STEM education. Many countries are working to keep pace to this transformation by making progress with innovations in science and technology. Increasing importance of innovation from the social point of view also transformed the education systems responsible for the training of the individuals who will carry out the innovation, which led to the appearance of Education 4.0. Education 4.0 is based on innovation-focused practices carried out by individuals or teams [40]. It is very important to ask questions, to look at the problem from different disciplines, to have knowledge about different disciplines, to consider analytically and creatively for the individuals who are going to reconstruct by doing innovation [89]. The fact that the level of economic development of countries is closely related to improvements and innovations in the fields of Science, Technology, Engineering, Mathematics (STEM) has led to the attention to be drawn to these fields. The studies and developments in STEM fields are of great importance for our country to be able to compete with the developed countries which have a say in the global economy. For that reason, it is increasingly important to train teachers who are practitioners of STEM education, which is contemplated to play an important role in the future of countries. The training of teachers who apply STEM education plays a critical role in achieving the expected results from this approach.

Ministry of Education and Education Faculties should determine the qualifications of teachers who will implement the STEM education approach by conducting a joint study on pre-service education of teachers. In addition to this, they should ensure that their undergraduate programs are being developed in such a way that pre-service teachers will acquire these qualifications. Training of teachers in pre-service will play an important role in achieving the expected results from the approach. Two ways in which expectations can be met to teach STEM education approach to pre-service teacher can be suggested; first, the courses in the undergraduate programs can provide to pre-service teachers the necessary knowledge and skills in STEM education altogether; the second, there can be the separate course(s) under the name of STEM education. But it will be easier to open a new course in the undergraduate programs than to change the undergraduate programs altogether.

\section{REFERENCES}

[1] Akaygun, S. \& Aslan Tutak, F. (2016). STEM images revealing stem conceptions of pre-service chemistry and mathematics teachers. International Journal of Education in Mathematics, Science and Technology, 4(1), 56-71

[2] Akçay, S., Aydoğdu, M., Yıldırım, H. İ. \& Şensoy, Ö. (2005). Fen eğitiminde ilköğretim 6. Sınıflarda çiçekli bitkiler konusunun öğretiminde bilgisayar destekli öğretimin öğrenci başarısına etkisi. Kastamonu Eğitim Dergisi, 103-116.

[3] Akgündüz, D., Aydeniz, M., Çakmakçı, G., Çavaş, B., Çorlu, M. S., Öner, T. \& Özdemir, S. (2015a). STEM Eğitimi Türkiye Raporu. İstanbul: İstanbul Aydın Üniversitesi.

[4] Akgündüz, D., Ertepınar, H., Ger, A. M., Kaplan Sayı, A. \& Türk, Z. (2015b). STEM Eğitimi Çalıştay Raporu Türkiye STEM Ĕgitimi Üzerine Kapsaml Bir Değerlendirme. İstanbul: İstanbul Aydın Üniversitesi.

[5] Akpınar, Ş. (2014). Öğretmen adaylarının problem çözme ve sosyal becerilerinin incelenmesi. (Yüksek lisans tezi).

[6] American Association for the Advancement of Science (AAAS). (1989). Science for all Americans. New York, NY: Oxford University.

[7] American Association for the Advancement of Science (AAAS). (1993). Benchmarks for science literacy. New York: Oxford University.

[8] Apedoe, X. S., Reynolds, B., Ellefson, M. R. \& Schunn, C. D. (2008). Bringing engineering design into high school science classrooms: The heating/cooling unit. Journal of Science Education and Technology, 17(5), 454-465.

[9] Aslan-Tutak, F., Akaygun, S. \& Tezsezen, S. (2017). İşbirlikli FeTeMM (Fen, Teknoloji, Mühendislik, Matematik) eğitimi uygulaması: kimya ve matematik ögretmen adaylarının FeTeMM farkındalıklarının incelenmesi. Hacettepe Üniversitesi Ĕ̈itim Fakültesi Dergisi, 32(4): 794-816.

[10] Aydin, E. \& Delice, A. (2007). Experiences of mathematics teachers in a series of science experiments. Paper presented at the 6th WSEAS International Conference on Education and Educational Technology, Venice, Italy, November 2007.

[11] Barker, B. S. \& Ansorge, J. (2007). Robotics as means to increase achievement scores in an informal learning environment. Journal of Research on Technology in Education, 39(3), 229-243.

[12] Barrett, B. S., Moran, A. L. \& Woods, J. E. (2014). Meteorology meets engineering: an interdisciplinary STEM module for middle and early secondary school students. International Journal of STEM Education, 1(1), 6.

[13] Başkan, Z., Alev, N. \& Karal, I. S. (2010). Physics and mathematics teachers' ideas about topics that could be related or integrated. Procedia-Social and Behavioral Sciences, 2(2), 1558-1562.

[14] Becker, K. \& Park, K. (2011). Effects of integrative approaches among science, technology, engineering, and mathematics (STEM) subjects on students' learning: A preliminary meta-analysis. Journal of STEM Education: Innovations and Research, 12(5/6), 23.

[15] Berlin, D. F. \& Lee, H. (2005). Integrating science and mathematics education: Historical analysis. School Science and Mathematics, 105(1), 15-24. Retrieved from 
http://onlinelibrary.wiley.com/doi/10.1111/j.1949-8594.20 05.tb18032.x/pdf.

[16] Berlin, D. F. \& White, A. L. (2010). Preservice mathematics and science teachers in an integrated teacher preparation program for grades 7-12: A 3-year study of attitudes and perceptions related to integration. International Journal of Science and Mathematics Education, 8(1), 97-115.

[17] Braga, J. L. (1972). Teacher role perception. Journal of Teacher Education, 23(1), 53-57.

[18] Breiner, J. M., Harkness, S. S., Johnson, C. C., \& Koehler, C. M. (2012). What is STEM? A discussion about conceptions of STEM in education and partnerships. School Science and Mathematics, 112(1), 3-11.

[19] Büyüköztürk, Ş., Çakmak, E. K., Akgün, Ö. E., Karadeniz, Ş. \& Demirel, F. (2014). Bilimsel araştırma yöntemleri. Ankara: PegemA.

[20] Bybee, R. W. (2013). The case for STEM education: Challenges and opportunities. USA: National Science Teachers Association.

[21] Corlu, M. (2012). A pathway to STEM education: Investigating pre-service mathematics and science teachers at Turkish universities in terms of their understanding of mathematics used in science (Doctoral dissertation).

[22] Corlu, M. S. (2014). FeTeMM eğitimi makale çağr mektubu. TurkishJournal of Education, 3(1).

[23] Corlu, M. S., Capraro, R. M. \& Capraro, M. M. (2014). Introducing STEM education: implications for educating our teachers for the age of innovation. Egitim ve Bilim, $39(171)$.

[24] Çakmak, N. (2015). Örnek olay ve altı sapkalı düsünme etkinliklerinin fen bilgisi ögrretmen adaylarının eleştirel düşünme becerilerine etkisinin incelenmesi. (Yüksek lisans tezi).

[25] Çakmakçı, G. (2016). Dünya ile rekabet için STEM şart. Hürriyet.

[26] Corlu, M. A. \& Corlu, M. S. (2012). Scientific inquiry based professional development models in teacher education. Educational Sciences: Theory \& Practice, 11(1), $5-20$.

[27] Demir, K. (2008). Bütünleştirilmiş öğretim programının işbirliğine dayalı ve proje tabanlı ögrenme yaklaşımıyla uygulanmasinın etkililiği. (Doktora tezi).

[28] Dugger, W. E. (2010). Evolution of STEM in the United States.

[29] Dutta, S., Lanvin, B. \& Wunsch-Vincent, S. (2017). The global innovation index 2017: Innovation feeding the world Switzerland: World Intellectual Property Organization (WIPO) and the Confederation of Indian Industry (CII).

[30] Elliott, B., Oty, K., McArthur, J. \& Clark, B. (2001). The effect of an interdisciplinary algebra/science course on students' problem solving skills, critical thinking skills and attitudes towards mathematics. International Journal of Mathematical Education in Science and Technology, 32(6), 811-816.

[31] Freeman, B. (2013). Science, Mathematics, Engineering and Technology (STEM) in Australia: Practice, policy and programs. Melbourne: Australian Council of Learned Academies.

[32] Gökçe, O. (2006). İçerik analizi kuramsal ve pratik bilgiler. Ankara: Siyasal.

[33] Gökdere, M. \& Çepni, S. (2003). Üstün yetenekli çocuklara verilen değerler eğitiminde öğretmenin rolü. Değerler Eğitimi Dergisi, 1 (2), 93-107.

[34] Gömleksiz, M., Yaşar, S., Sağlam, M., Hakan, A., Sözer, E. \& Gözütok, D. (2005). Ĕ̌itim programları ve öğretim alanı profesörler kurulu ilkögretim 1-5. sinıflar ögretim programlarını değerlendirme toplantısı sonuç bildirisi. Eskişehir: Anadolu Üniversitesi.

[35] Güler, M. H. \& Sağlam, N. (2002). Biyoloji öğretiminde bilgisayar destekli öğretimin ve çalışma yapraklarının öğrencilerin başarısı ve bilgisayara karşı tutumlarına etkileri. Hacettepe Üniversitesi Eğitim Fakültesi Dergisi, 23(23).

[36] Gürdal, A., Şahin, F. \& Bayram, H. (1999). İlköğretim öğretmen adaylarının enerji konusunda bütünlüğü sağlama ve ilişski kurma düzeyleri üzerine bir araştırma. D.E.Ü. Buca Eğitim Fakültesi Dergisi Özel Sayı, 10, 382-395.

[37] Güven, G. \& Sülün, Y. (2012). Bilgisayar destekli öğretimin 8. sınıf fen ve teknoloji dersindeki akademik başarıya ve öğrencilerin derse karşı tutumlarına etkisi. Türk Fen Eğitimi Dergisi, 9(1), 68-79.

[38] Hacioglu, Y., Yamak, H. \& Kavak, N. (2016). Mühendislik Tasarim Temelli Fen Egitimi ile Ilgili Ögretmen Görüsleri/Teachers' Opinions Regarding Engineering Design Based Science Education. Bartin Üniversitesi Egitim Fakültesi Dergisi, 5(3), 807.

[39] Hagger, H., Burn, K., Mutton, T. \& Brindley, S. (2008). Practice makes perfect? Learning to learn as a teacher. Oxford Review of Education, 34(2), 159-178.

[40] Harkins, A. M. (2008). Leapfrog Principles and Practices: Core Components of Education 3.0 and 4.0. Futures Research Quarterly, VIII, 28 March 2008.

[41] Hartzler, D. S. (2000). A meta-analysis of studies conducted on integrated curriculum programs and their effects on student achievement. (Doctoral dissertation).

[42] Hill, H. C., Schilling, S. G. \& Ball, D. L. (2004). Developing measures of teachers' mathematics knowledge for teaching. The Elementary School Journal, 105(1), $11-30$

[43] Holdren, J. P., Lander, E. S. \& Varmus, H. (2010). Prepare and inspire: $\mathrm{K}-12$ education in science, technology, engineering, and math (STEM) for America's future. Washington, DC: President's Council of Advisors on Science and Technology.

[44] H-STEM Lab (2014). Bilim ve İnovasyon Eğitiminde Hacettepe Üniversitesi'nin Rolü. Hacettepe Bilim, Kültür ve Teknoloji Dergisi, Eylül-Ekim.

[45] Idris, N., Daud, M. F., Meng, C. C. \& Eu, L. K. (2013). Country Report Singapore STEM. Melbourne: Australian Council of Learned Academies (ACOLA).

[46] International Technology Education Association (ITEA) 
(2003). Advancing Excellence in Technological Literacy: Student Assessment, Professional Development, and Program Standarts.

[47] International Technology Education Association (ITEA) (2007). Standards for Technological Literacy: Content for the study of technology.

[48] International Technology and Engineering Educators Association (ITEA) (2013). Building a Statewide Model for Technology Education with EbD. Technology and Engineering Teacher 73(1).

[49] International Technology Education Association (ITEA) (2009). The overlooked STEM imperatives: Technology and Engineering K-12 Education.

[50] Isık, A. D. \& Saygıll, G. (2015). Yaratıcılığı Geliştirme Tekniklerinin Öğrenilmesinin Yaratıcı Düșünme Becerileri Üzerindeki Etkisi. [Özel say1]. Bartın Üniversitesi Eğitim Fakültesi Dergisi, 133-139.

[51] Israel, M., Maynard, K., \& Williamson, P. (2013). Promoting literacy-embedded, authentic STEM instruction for students with disabilities and other struggling learners. Teaching Exceptional Children, 45(4), 18-25.

[52] İzci, E. \& Koç, S. (2012). Öğretmen adaylarının yaşam boyu öğrenmeye ilişkin görüşlerinin değerlendirilmesi. Adıyaman Üniversitesi Sosyal Bilimler Enstitüsü Dergisi, 2012(9).

[53] Johnson, A. P. (2000). It's time for Madeline Hunter to go: A new look at lesson plan design. Action in teacher education, 22(1), 72-78.

[54] Jon, J. E. \& Chung, H. I. (2013). STEM Report - Republic of Korea. Melbourne: Australian Council of Learned Academies.

[55] Judson, E. \& Sawada, D. (2000). Examining the effects of a reformed junior high school science class on students' math achievement. School Science and Mathematics, 100(8), 419-425.

[56] Karademir, E. (2009). Bilgisayar destekli öğretimin ögrencilerin fen ve teknoloji dersi elektrik ünitesindeki akademik bașarı düzeylerine, bilimsel süreç becerilerine ve tutumlarına etkisi. (Yüksek lisans tezi).

[57] Karakuş, M., Türkkan, B. T. \& Karakuş, F. (2017). Fen Bilgisi ve İlköğretim Matematik Öğretmenlerinin Disiplinlerarası Yaklaşıma Yönelik Görüşlerinin Belirlenmesi. İlkögretim Online, 16(2).

[58] Karasar, N. (2014). Bilimsel Araştırma Yöntemi. Ankara: Nobel.

[59] Kärkkäinen, K. \& Vincent-Lancrin, S. (2013). “Sparking Innovation in STEM Education with Technology and Collaboration: A Case Study of the HP Catalyst Initiative”. Paris: OECD Education Working Papers (Report No. 91).

[60] Katehi, L., Pearson, G. \& Feder, M. (2009). The status and nature of K-12 engineering education in the United States. The Bridge, 39(3), 5-10.

[61] LaForce, M., Noble, E., King, H., Century, J., Blackwell, C., Holt, S., ... Loo, S. (2016). The eight essential elements of inclusive STEM high schools. International Journal of STEM Education, 3(1), 21.
[62] Langdon, D., McKittrick, G., Beede, D., Khan, B. \& Doms, M. (2011). STEM: Good Jobs Now and for the Future. ESA Issue Brief, 03-11. US Department of Commerce.

[63] Lantz, H. B. (2009). Science, Technology, Engineering, and Mathematics (STEM) education: What form? What function? CurrTech Integrations, Baltimore.

[64] Marulcu, İ. \& Höbek, K. M. (2014). Teaching Alternate Energy Sources to 8th Grades Students by Engineering Design Method. Middle Eastern \& African Journal of Educational Research MAJER Issue: 9

[65] Meyrick, K. M. (2011). How STEM education improves student learning. Meridian K-12 School Computer Technologies Journal, 14(1), 1-6.

[66] Ministry of National Education (MoNE) (2016). STEM Eğitimi Raporu. Ankara: Yenilik ve Eğitim Teknolojileri Genel Müdürlüğü (YEĞİTEK).

[67] Ministry of National Education (MoNE) (2017a). Fen Bilimleri Dersi Öğretim Programı (İlkokul ve Ortaokul 3., 4., 5., 6., 7. ve 8. Siniflar)

[68] Ministry of National Education (MoNE) (2017b). Teknoloji ve Tasarım Dersi Öğretim Programı (Ortaokul 7. ve 8. Siniflar).

[69] Ministry of National Education (MoNE) (2017c). Bilişim Teknolojileri ve Yazılım Dersi Öğretim Programı(Ortaokul 5. ve 6. Siniflar).

[70] Ministry of National Education (MoNE) (2017d) Matematik Dersi Öğretim Programı (İlkokul ve Ortaokul 3., 4., 5., 6., 7. ve 8. Siniflar)

[71] National Research Council (NRC) (1996). National Science Education Standards. Washington, DC: The National Academyies.

[72] National Research Council (NRC) (2009). Engineering in K-12 education: Understanding the status and improving the prospects. Washington, DC: National Academies.

[73] National Research Council (NRC) (2010). Exploring the Intersection of Science Education and 21st Century Skills: A Workshop Summary. Washington, DC: The National Academies.

[74] National Research Council (NRC) (2011a). Successful K-12 STEM Education: Identifying Effective Approaches in Science, Technology, Engineering, and Mathematics. Washington, DC: The National Academies.

[75] National Research Council (NRC) (2011b). Successful STEM Education: A Workshop Summary. Washington, DC: The National Academies.

[76] National Research Council (NRC) (2012). A framework for K-12 science education: Practices, crosscutting concepts, and core ideas. Washington, DC: The National Academies.

[77] Özcan, E. (2013). Probleme dayalı öğrenmenin fen ögretmen adaylarının problem çözme becerileri, akademik başarıları ve tutumları üzerindeki etkisi. (Yüksek lisans tezi).

[78] Özdemir, S. M. (2011). Toplumsal Değişme ve Küreselleşme Bağlamında Eğitim ve Eğitim Programları: Kavramsal Bir Çözümleme. Journal of Kirsehir Education 
Faculty, 12(1).

[79] Öztürk, İ. H. (2012). Öğretimin planlanmasında öğretmenin rolü ve özerkliği: Ortaöğretim tarih öğretmenlerinin yıllık plan hazırlama ve uygulama örneği. Kuram ve Uygulamada Ĕ̌itim Bilimleri, 12(1), 271-299.

[80] Sanders, M. E. (2009). Stem, stem education, stemmania. The Technology Teacher, 68(4), 20-26.

[81] Sanders, M. E. (2012). Integrative STEM education as "best practice". Paper presented at the 7th Biennial International Technology Education Research Conference Queensland, Australia, August 2012.

[82] Savaş, B. (2006). Illköğretim 4 sinıfta bütünleştirilmiş ünite ve yapılandırmacı yaklașımın öğrencilerin öğrenme düzeylerine, öğrenmeye karşı tutumlarına, akademik özgüvenlerine etkisi. (Doktora tezi).

[83] Shernoff, D. J., Sinha, S., Bressler, D. M. \& Ginsburg, L. (2017). Assessing teacher education and professional development needs for the implementation of integrated approaches to STEM education. International Journal of STEM Education, 4(1), 13.

[84] Shulman, L. S. (1986). Those who understand: Knowledge growth in teaching. Educational Researcher, 15(2), 4-14.

[85] Sulak, S. A. (2002). Matematik dersinde bilgisayar destekli ögretimin ögrenci başarı ve tutumlarına etkisi (Yüksek lisans tezi).

[86] Tartuk, M. (2015). Sosyal bilgiler ögretmen adaylarının eleştirel düşünme ve empati kurma eğilimlerinin araștırılması. (Yüksek lisans tezi).

[87] Tomei, A., Dawson, E. \& Dillon, J. (2013). A study of Science, Technology, Engineering and Mathematics education in United Kingdom. Melbourne: Australian Council of Learned Academies.

[88] Turna, Ö. \& Bolat, M. (2015). Eğitimde disiplinleraras1 yaklaşımın kullanıldığı tezlerin analizi. Ondokuz Mayıs Üniversitesi Eğitim Fakültesi Dergisi, 34(1), 35-55.

[89] TÜSİAD. (2014). STEM Alanında Eğitim Almış Iş̧ǚcüne Yönelik Talep ve Beklentiler Araştırması. TÜSİAD-T/2014, 10-557, Ekim, 2014.

[90] TÜSİAD. (2017). Basın Bülteni.

[91] WIPO Economics and Statistics Series. (2016) World Intellectual Property Indicators. Switzerland: World Intellectual Property Organization.

[92] Williams, J. (2011). STEM education: Proceed with caution. Design and Technology Education: An International Journal, 16(1).

[93] Yeşilpınar, M. (2011). Sinıf öğretmenlerinin ve ögrretmen adaylarının eleştirel düşünmenin ögrretimine yönelik yeterliklerine ilişkin görüşler. (Yüksek lisans tezi).

[94] Yıldırım, A. ve Şimşek, H. (2006). Sosyal bilimlerde nitel araştırma yöntemleri. Ankara: Seçkin.

[95] Yıldırım, A., \& Öztürk, E. (2002). Sınıf Öğretmenlerinin Günlük Planlarla İlgili Algıları: Öncelikler, Sorunlar ve Öneriler, İlköğretim-Online, 1 (1), 17-27. 